\title{
THE EFFECTS OF DIFFERENT POSTHARVEST APPLICATIONS ON SOME PHYSICOCHEMICAL PROPERTIES IN 'RUBYGEM' AND 'SABRINA' STRAWBERRY (FRAGARIA X ANANASSA DUCH.) CULTIVARS
}

\author{
TEKIN, O. - ÇAVUŞOĞLU, Ş.* \\ Horticulture Department, Agriculture Faculty, Van Yüzüncü Yll University, Van, Turkey \\ (phone: +90-432-225-17-01) \\ *Corresponding author \\ e-mail: seydacavusoglu@yyu.edu.tr \\ (Received 22 $2^{\text {nd }}$ Jun 2018; accepted $7^{\text {th }}$ Aug 2018)
}

\begin{abstract}
This study aimed to determine the efficacy of two standards strawberry (Fragaria $\mathrm{x}$ ananassa Duch.) cultivars 'Rubygem' and 'Sabrina' grown under protected cultivation system in Mersin province in Turkey. The fruit quality preservation during storage in Modified atmosphere packaging (MAP) at different storage temperatures as well as preservative compatibility under Ultraviolet-C (UV-C), hot water and combined applications were studied. Strawberry fruits kept in cold temperatures $\left(0{ }^{\circ} \mathrm{C}\right.$ and $5{ }^{\circ} \mathrm{C}$ ) for 20 days and biochemical changes (total phenolic content, total antioxidant capacity, vitamin $\mathrm{C}$ content and sugar content) were measured after harvest and storage The 'cv. Rubygem' kept its quality for 16 days in all treatments and for 20 days in UV-C and UV-C + hot water applications when kept at $0{ }^{\circ} \mathrm{C}$. Also, the fruits stored at $5{ }^{\circ} \mathrm{C}$ kept their quality for 12 days and it was observed that hot water and UV-C + hot water treatments got better results in the same period and at the same storage temperature. In the 'cv. Sabrina' results showed that fruit samples at 0 ${ }^{\circ} \mathrm{C}$ were successfully maintained in control as well as the other 3 treatments until the $12^{\text {th }}$ day. The preservation was continued in UV-C, hot water and combined treatments on the $16^{\text {th }}$ day of the storage and the best ones were the hot water and UV-C + hot water at the end of the $20^{\text {th }}$ day. As a result, it was observed that total phenolic contents, total antioxidant activity and sugar were found decrease at the end of storage for both cultivars while fluctuations in vitamin C.
\end{abstract}

Keywords: biochemical changes, hot water, UV-C, sugar, vitamin C, total phenolic, antioxidant

\section{Introduction}

Strawberry (Fragaria $\mathrm{x}$ ananassa Duch.) fruit is consumed abundantly by consumers and has many positive effects (Çağlarırmak, 2006) such as strengthening defense mechanisms and protecting against cancer and infections, protection against DNA damage in the organism (Vinson et al., 2001), protection against cardiovascular disease and lipid peroxidation, because it is rich in antioxidants (Wang et al., 1996; Araque et al., 2018) including anthocyanins, flavanoids and phenolic materials, as well as its unique color, flavor (Gao et al., 2016), aroma, texture, high-order elagic acid (Aybak, 2005).

It is very important to protect the post-harvest quality of strawberries, because they are located in a group of fruit berries that break down quickly and easily after harvest.

The main soluble sugars found in the structure of strawberry berry are glucose, fructose and sucrose, and glucose and fructose are known to dominate sucrose in total sugar content (Cordenunsi et al., 2003).

Strawberry fruit contains as high as $92 \%$ water. For this reason, water loss is one of the important issues after harvest. In addition to water loss, a number of insecticides and fungicides are used both on the field and before harvesting to prevent the losses 
caused by diseases and pests. Applications that are environmentally friendly to prevent postharvest decay include applications such as hypobaric applications (Romanzzi et al., 2001), modified atmosphere packaging (Silva et al., 1999), Ultraviolet-C (UV-C) and hot water applications (Keskin et al., 2014, 2015).

For the last ten years UV-C $(180-280 \mathrm{~nm} \lambda=254 \mathrm{~nm})$ in horticulture products has been considered as an alternative to fungicides to control post-harvest diseases. Moreover, many investigators have reported that UV-C protects fruits and vegetables against decay after harvesting (Marquenie et al., 2003; Allende and Artes, 2003; Allende et al., 2006; Keskin et al., 2014, 2015). It has also been used to delay the ripening of fruits and vegetables by extending their shelf life (Darvishi et al., 2012). When UV-C is applied in appropriate dose and duration, it increases the accumulation of phytoalexins (Keskin and Kunter, 2017), which is effective on the mechanism against disease and damage plants (Keskin et al., 2014, 2015). However, there is still a lot of work to be done to optimize UV-C applications.

In recent years, hot water applications have been implemented to increase the shelf life of fruits and vegetables and to reduce the use of chemical substances in the fight against diseases and pests (Lurie, 1998). Hot water applications are made by immersion (Barkai-Golan and Phillips, 1991) or by special hot water spraying (Fallik et al., 1996).

Due to short life time of post harvested strawberry fruit, the effect of modified atmosphere packaging (MAP) with different treatments have been widely considered.

In this study, effects of different postharvest treatments including UV-C and hot water were studied on biochemical changes of two commercially strawberry varieties stored at different temperatures in in MAP (modified atmosphere packaging) condition.

\section{Materials and methods}

\section{Cultivars used in research}

In the study, 'Sabrina' and 'Rubygem' strawberry cultivars, which are grown under greenhouse by a private company named Roseland and harvested in similar maturity in Tarsus district in Mersin province in Turkey, were used as research materials.

Strawberry fruit was first pre-cooled at $0{ }^{\circ} \mathrm{C}$ for 1 day. Later, the fruits of the same maturity were divided into 4 different groups. The first group of fruits was separated as controls. The second group of fruits was irradiated with $254 \mathrm{~nm} \mathrm{UV-C}\left(0.25 \mathrm{~kJ} \mathrm{~m}^{-2}\right)$ with Vilber Lourmat UV-C lamp on both surfaces as $5 \mathrm{~min}$ at $20 \mathrm{~cm}$ distance. The third group of fruits was kept at $60{ }^{\circ} \mathrm{C}$ for 10 seconds in a hot water bath. In the fourth group, both UV-C and hot water applications were applied. Then fruit samples were placed in 250 gr plastic bags.

Fruits were maintained at $0{ }^{\circ} \mathrm{C}$ and $5{ }^{\circ} \mathrm{C}$ in Van Yüzüncü Yıl University Faculty of Agriculture Department of Horticulture's cold-air storages with a relative humidity of $90-95 \%$ for 20 days.

\section{Total phenolic substance amount and total antioxidant activity}

Total phenolic contents in 'Rubygem' and 'Sabrina' strawberry cultivars were determined by spectrophotometer (Varian Bio 100, Australia) by Folin-Ciocaltaeu calorimetric method (Swain and Hillis, 1959). Absorbance values of the solutions 
were read in spectrophotometer (Thermo Fisher Scientific, G10S UV-Vis) at $725 \mathrm{~nm}$ wavelength and the total amount of phenolic substance expressed as gallic acid equivalent (GAE) $\mathrm{mg} \mathrm{kg}^{-1}$ fresh weight (FW).

Ferric Reducing Antioxidant Power (FRAP) (Iron (III) Reduction Antioxidant Power) method was used to determine antioxidant activity (Benzie and Strain, 1996). $300 \mu \mathrm{L}$ freshly prepared FRAP reagent [25 mL acetate buffer $(300 \mathrm{mmol} / \mathrm{L}, \mathrm{pH} 3.6)$, $2.5 \mathrm{~mL} \mathrm{TPTZ}(10 \mathrm{mmol} / \mathrm{L})$ in $40 \mathrm{mmol} / \mathrm{L} \mathrm{HCl}$, and $2.5 \mathrm{~mL} \mathrm{FeCl}{ }_{3} \cdot 6 \mathrm{H}_{2} \mathrm{O}$ solution (20 mmol/L) were mixed as required to prepare working FRAP reagent] was warmed to $37^{\circ} \mathrm{C}$, and a reagent blank reading was taken at $593 \mathrm{~nm} ; 10 \mu \mathrm{L}$ of each fraction extract solution of an appropriate concentration was then added along with $30 \mu \mathrm{L}$ $\mathrm{H}_{2} \mathrm{O}$. The 0-4 min absorbance change $\left(\Delta A_{593 \mathrm{~nm}}\right)$ was calculated for each sample and related to $\Delta A_{593 \mathrm{~nm}}$ of a $\mathrm{Fe}^{2+}$ standard solution tested in parallel to obtain the FRAP value of each sample. Antioxidant activity values were reported as $\mu$ mol trolox equivalent (TE) $\mathrm{mg}^{-1}$.

\section{Vitamin C (ascorbic acid)}

The method specified by Cemeroğlu (2007) was applied to determine the content of vitamin C. $3 \mathrm{~g}$ of the strawberry fruit were weighed and homogenized in $6 \mathrm{ml}$ of $6 \%$ metaphosphoric acid, then centrifuged at $12000 \mathrm{rpm}$ for $15 \mathrm{~min}$ at $4{ }^{\circ} \mathrm{C}$. In the HPLC (Agilent 1100 series) analyzes, C vitamins C18 (Phenomenex Luna C18, 250 x 4.60 $\mathrm{mm}, 5 \mu$ ) were performed. Readings was carried out in the DAD (DE33225146) detector at a wavelength of $254 \mathrm{~nm}$. L-ascorbic acid (Sigma A5960), prepared at different concentrations, was used to identify vitamin $\mathrm{C}$ pick and to determine the amount of vitamin C (Karadogan and Keskin, 2017).

\section{Sugar content}

After the fruit samples of 'cv. Rubygem' and cv. 'Sabrina' were homogenized, a 5 $\mathrm{g}$ sample from each replicate was added in $10 \mathrm{ml}$ of $6 \%$ metaphosphoric acid and then centrifuged at $15.000 \mathrm{rpm}$ for $15 \mathrm{~min}$ at $4{ }^{\circ} \mathrm{C}$. Sugar determinations were made on HPLC (Agilent 1100 series) after filtration through filters with a hole diameter of $0.45 \mathrm{~mm}$ in the supernatant sample. For this purpose, Phenomenex Rezex RCM monosaccharide column, $80 \%$ acetonitrile and refractive index detector were used as carrier phase. The definitions for sucrose, glucose, fructose and maltose were made using external standards, taking into consideration the structural changes of 'Rubygem' and 'Sabrina' (Özgökçe, 2016).

\section{Statistical analysis}

Experiments were conducted with three replication. The descriptive statistics for the traits studied are expressed as mean and standard error. In terms of these characteristics, factorial (Four Factors) Variance Analysis was performed to determine whether there was a difference between storage period, applications, temperature and cultivars. Following the variance analysis, Duncan test was used to identify the different groups. The statistical significance level was taken as $\mathrm{p}<0.05$ in the calculations and the SPSS statistical package program was used for the calculations. 


\section{Results}

\section{Total phenolic content}

During storage, it was observed that total phenolic contents of the 'cv. Rubygem' and 'cv. Sabrina' strawberry cultivars decreased at both storage temperatures. In the 'cv. Rubygem' strawberry cultivar; the highest total phenolic content at $0{ }^{\circ} \mathrm{C}$ was found to be $498.486 \mathrm{mg} \mathrm{kg}^{-1}$ with UV-C on day 16 and the lowest value was found in the control group as $247.946 \mathrm{mg} \mathrm{kg}^{-1}$ on day 20 . At $5{ }^{\circ} \mathrm{C}$, the highest total phenolic content was determined in hot water application on day 8 as $496.054 \mathrm{mg} \mathrm{kg}^{-1}$, while the lowest value was found in the control group with $206.189 \mathrm{mg} \mathrm{kg}^{-1}$ on the $12^{\text {th }}$ day.

The highest total phenolic content in 'cv. Sabrina' was found to be in hot water application with $515.919 \mathrm{mg} \mathrm{kg}^{-1}$ on $8^{\text {th }}$ day and the lowest value was found in UV-C application on the $20^{\text {th }}$ day with $117.405 \mathrm{mg} \mathrm{kg}^{-1}$. At $5{ }^{\circ} \mathrm{C}$, it has been identified that the highest value application was $484.297 \mathrm{mg} \mathrm{kg}^{-1}$ with UV-C + hot water application on day 0 and the lowest total phenolic compound value was with UV-C application on day 8 with $385.784 \mathrm{mg} \mathrm{kg}^{-1}$ (Fig. 1).

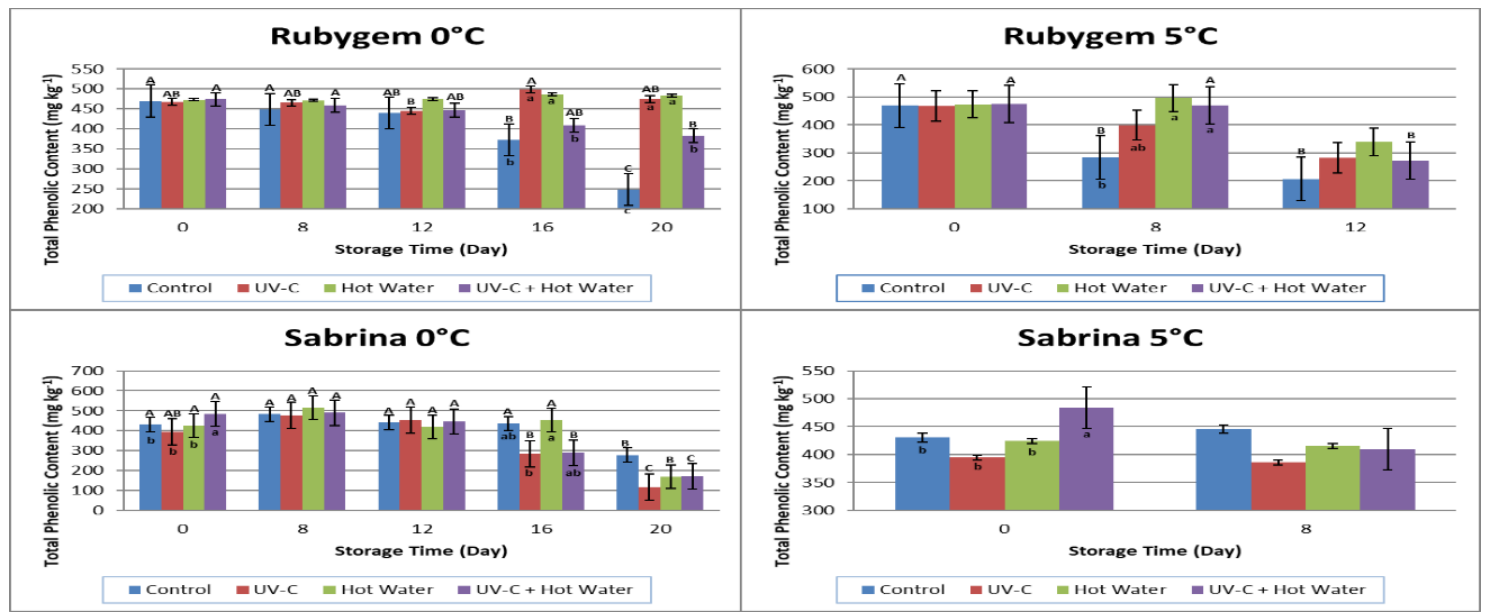

Figure 1. Changes in total phenolic content as a result of storage of ' $c v$. Rubygem' and 'cv. Sabrina' strawberry cultivars at 0 and $5^{\circ} C .(a, b, c, d$ : The difference between the applications of the same kind, same storage period and different lower case letters at the same storage temperature is significant $(p<0.05)$ [Comparison of applications]. A, B, C, D: The difference between storage times of the same kind, same application and different capital letters at the same storage temperature is significant $(p<0.05)$ [Comparison of storage periods])

\section{Total antioxidant activity}

Total antioxidant activity was found to decrease at the end of storage at both types and at the storage temperature. Therefore, in the 'cv. Rubygem', the highest value in total antioxidant activity at $0{ }^{\circ} \mathrm{C}$ was found to be $73.650 \mathrm{mg} 100 \mathrm{~g}^{-1}$ in the hot water application and the lowest value in the control group with $9.600 \mathrm{mg}^{100 \mathrm{~g}^{-1}}$ in the $20^{\text {th }}$ day. The highest total antioxidant capacity at $5^{\circ} \mathrm{C}$ was found to be $66.300 \mathrm{mg} 100 \mathrm{~g}^{-1}$ in hot water at $0^{\text {th }}$ day, and the lowest total antioxidant value in $12^{\text {th }}$ day at $3.250 \mathrm{mg} 100 \mathrm{~g}^{-}$ ${ }^{1}$ in UV-C + hot water application. The 'cv. Sabrina' has the highest antioxidant value at $0{ }^{\circ} \mathrm{C}$, Hot water application with $47.250 \mathrm{mg} 100 \mathrm{~g}^{-1}$ on the $8^{\text {th }}$ day and hot water application on the $20^{\text {th }}$ day with the lowest value of $6.600 \mathrm{mg} 100 \mathrm{~g}^{-1}$. At $5{ }^{\circ} \mathrm{C}$, the 
highest antioxidant amount was $40.100 \mathrm{mg} 100 \mathrm{~g}^{-1} \mathrm{UV}-\mathrm{C}+$ hot water application on day 0 , while the lowest was $23.050 \mathrm{mg} 100 \mathrm{~g}^{-1} \mathrm{UV}-\mathrm{C}$ on day 8 (Fig. 2).

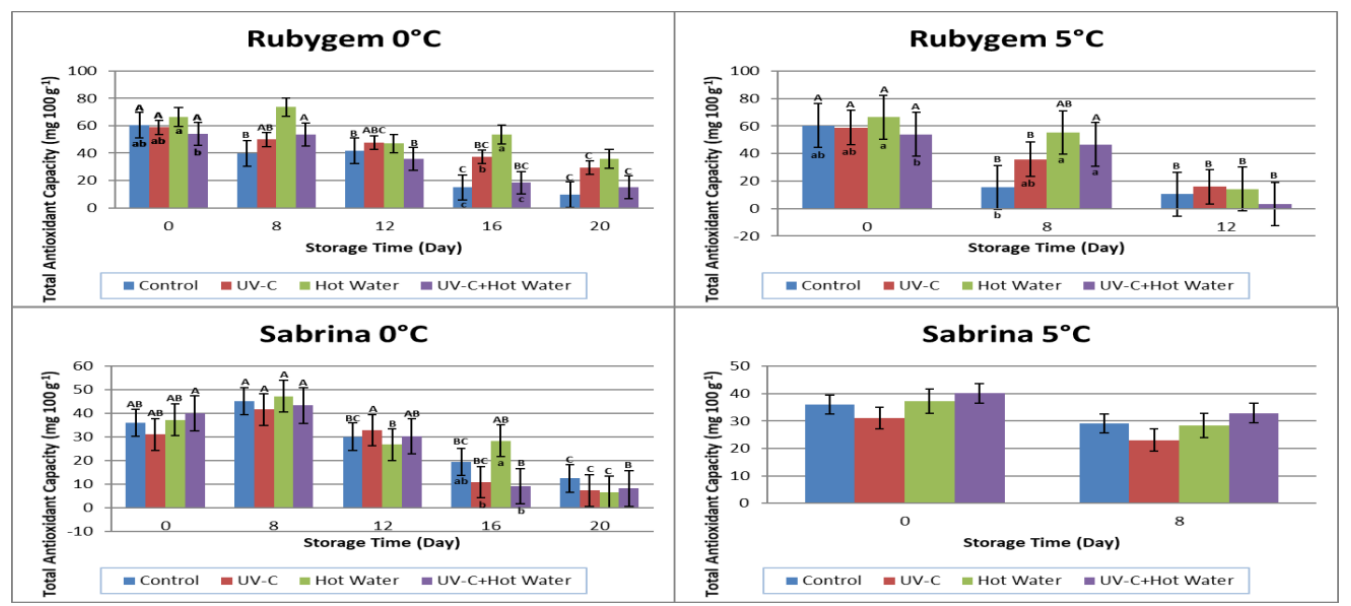

Figure 2. Changes total antioxidant capacity resulting from storage of 'Rubygem' and 'Sabrina' strawberry cultivars at 0 and $5{ }^{\circ} \mathrm{C}$

\section{Vitamin C (ascorbic acid)}

During storage, fluctuations in vitamin $\mathrm{C}$ value are observed. In the 'cv. Rubygem',

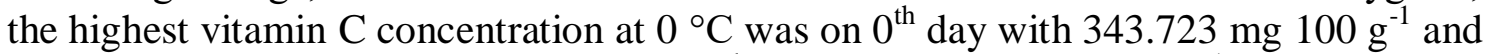
the lowest vitamin $\mathrm{C}$ concentration was $16^{\text {th }}$ day with $78.041 \mathrm{mg}^{100 \mathrm{~g}^{-1}}$ in UV-C + hot water application. According to analysis results, at $5{ }^{\circ} \mathrm{C}$, the highest value of vitamin $\mathrm{C}$

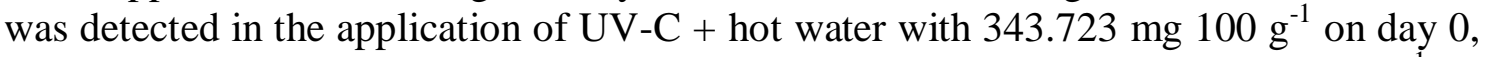

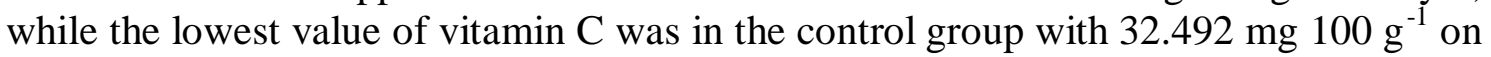
day 8 . When the 'cv. Sabrina' was examined, it was determined that the highest value at $0{ }^{\circ} \mathrm{C}$ was in hot water application with $382.854 \mathrm{mg} 100 \mathrm{~g}^{-1}$ on day 0 (Fig. 3).

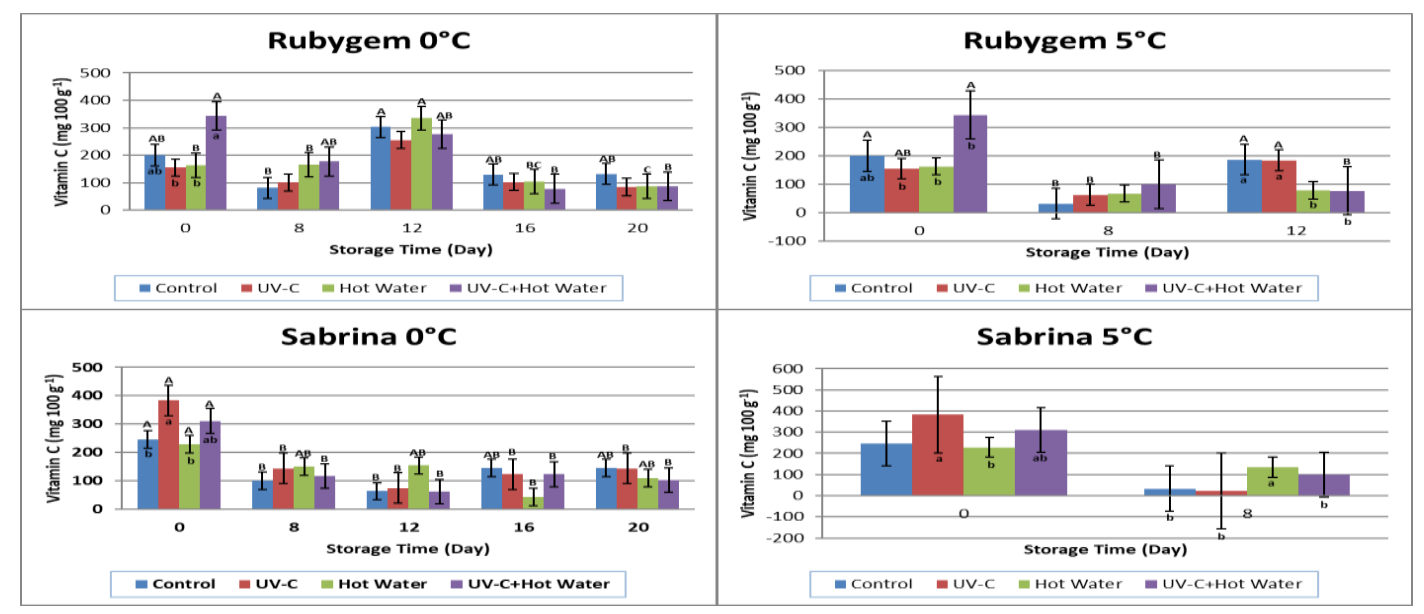

Figure 3. Changes in the value of vitamin $C$ as a result of storage of 'Rubygem' and 'Sabrina' strawberry cultivars at 0 and $5{ }^{\circ} \mathrm{C}$

The lowest values were found to be $43.273 \mathrm{mg} 100 \mathrm{~g}^{-1}$ and 16 days in hot water application. The highest value of $\mathrm{C}$ vitamins at $5{ }^{\circ} \mathrm{C}$ was found in $\mathrm{UV}-\mathrm{C}$ application at 
$382.854 \mathrm{mg} 100 \mathrm{~g}^{-1}$ on day 0 . The lowest value was determined in UV-C application on

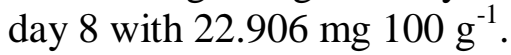

\section{Sugar content}

At the end of storage of the 'cv. Rubygem' at $0{ }^{\circ} \mathrm{C}$, the application with the highest fructose value was found in the control group on day 0 with $30.404 \mathrm{mg} \mathrm{g}^{-1}$, while the lowest value was found in the control group on day 20 with $4.180 \mathrm{mg} \mathrm{g}^{-1}$. At $5{ }^{\circ} \mathrm{C}$, the application with the highest fructose content was $30.404 \mathrm{mg} \mathrm{g}^{-1}$, while the lowest value application was with hot water at $3.876 \mathrm{mg} \mathrm{g}^{-1}$ on the $12^{\text {th }}$ day. When the variations in the 'cv. Sabrina' at $0{ }^{\circ} \mathrm{C}$ were examined, it was found that the highest fructose value was $22.793 \mathrm{mg} \mathrm{g}^{-1}$ on $8^{\text {th }}$ day in UV-C application and the lowest value was $1.539 \mathrm{mg} \mathrm{g}^{-}$ ${ }^{1}$ on $20^{\text {th }}$ day in UV-C application were determined according to the analysis results. At $5{ }^{\circ} \mathrm{C}$, the highest fructose value was found to be $22.556 \mathrm{mg} \mathrm{g}^{-1}$ with UV-C application on day 0 and the lowest value was found with UV-C application on day 8 with $11.372 \mathrm{mg} \mathrm{g}^{-1}$ (Fig. 4).

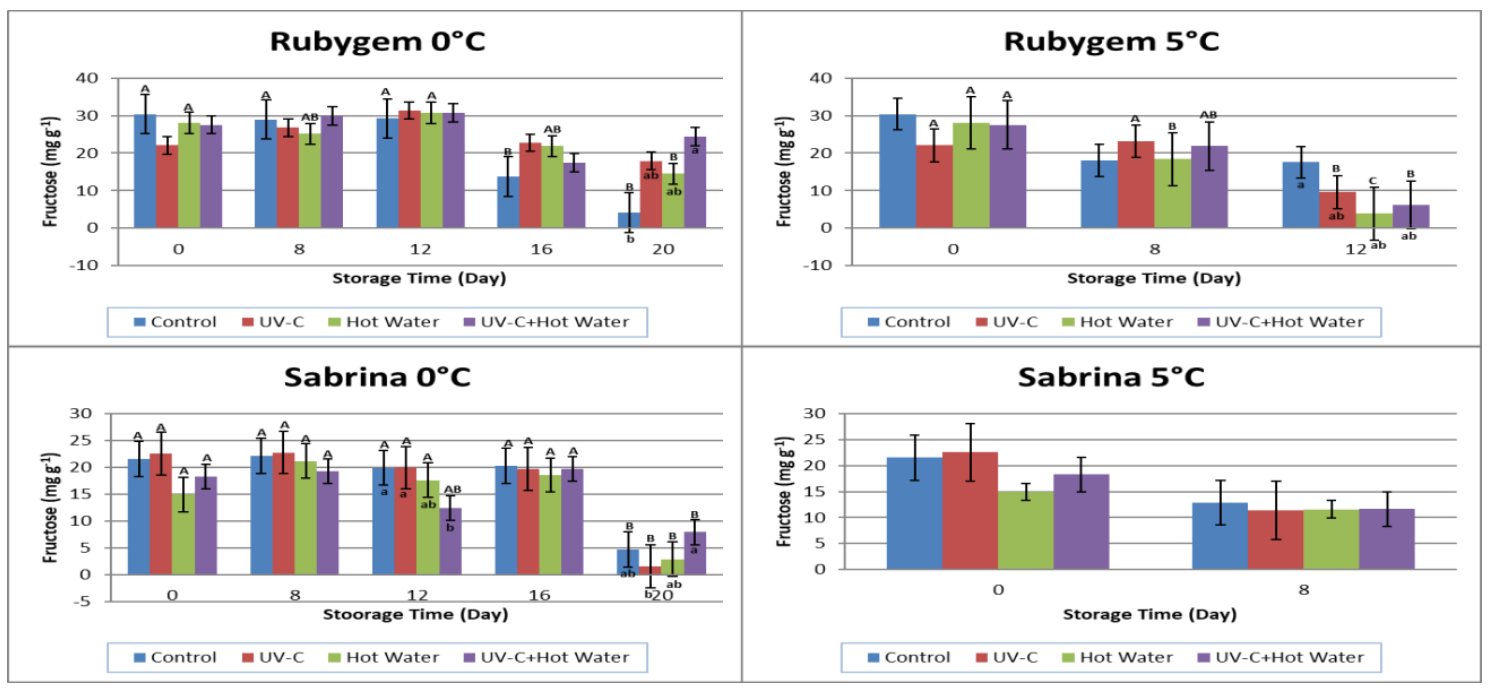

Figure 4. Changes in fructose values resulting from storage of 'Rubygem' and 'Sabrina' strawberry cultivars at 0 and $5{ }^{\circ} \mathrm{C}$

Glucose has decreased regularly at both cultivars and storage temperatures. In this context, it has been determined that the lowest values in both cultivars and storage temperatures are in hot water application. As a result of storage of the 'cv. Rubygem' at $0{ }^{\circ} \mathrm{C}$, the highest glucose value was found to be in the control group with $26.539 \mathrm{mg} \mathrm{g}^{-1}$ on day 0 , while the lowest value was found to be in hot water application with $0.577 \mathrm{mg}$ $\mathrm{g}^{-1}$ on the $20^{\text {th }}$ day. The highest glucose value for $5{ }^{\circ} \mathrm{C}$ was the control group with $26.539 \mathrm{mg} \mathrm{g}^{-1}$ on day 0 , while the lowest glucose value was found to be $1.086 \mathrm{mg} \mathrm{g}^{-1}$ on the $12^{\text {th }}$ day with hot water application. In the 'cv. Sabrina', it was determined that the maximum value at $0{ }^{\circ} \mathrm{C}$ was $16.945 \mathrm{mg} \mathrm{g}^{-1}$ in $\mathrm{UV}-\mathrm{C}$ application on $8^{\text {th }}$ day, while the lowest value was $0.762 \mathrm{mg} \mathrm{g}^{-1}$ in hot water on $20^{\text {th }}$ day. The highest glucose value at $5^{\circ} \mathrm{C}$ was found to be $16.284 \mathrm{mg} \mathrm{g}^{-1}$ in UV-C application on day 0 , while the lowest value was found in hot water application on day 8 with $5.676 \mathrm{mg} \mathrm{g}^{-1}$ (Fig. 5). 


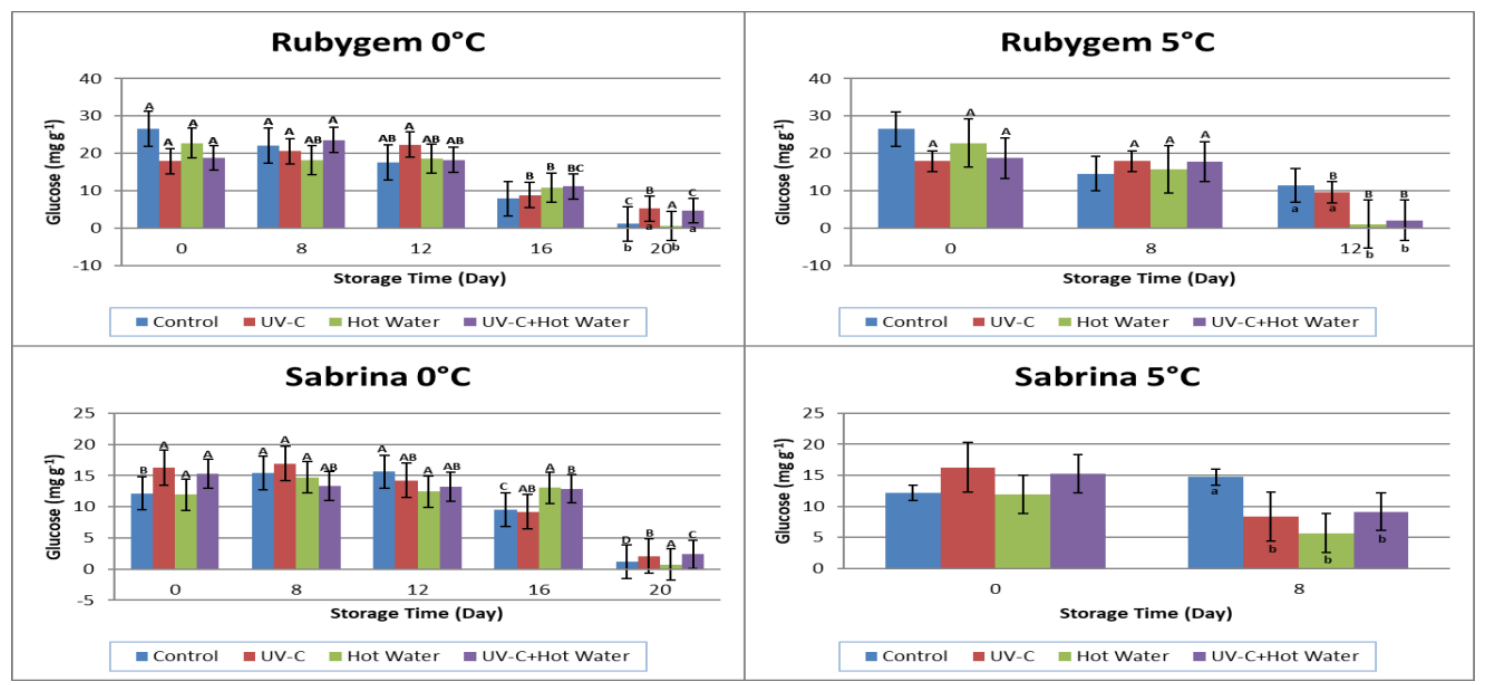

Figure 5. Changes in glucose values resulting from storage of 'Rubygem' and 'Sabrina' strawberry cultivars at 0 and $5^{\circ} \mathrm{C}$

When the changes in the sucrose value were examined, it was determined that there were fluctuations in both strawberry cultivars and storage temperatures. In the 'cv. Rubygem', it was determined that the highest value at $0{ }^{\circ} \mathrm{C}$ was $0.304 \mathrm{mg} \mathrm{g}^{-1}$, the UV-C + hot water application on $16^{\text {th }}$ day, and the lowest value was UV-C application on day 0 with $0.027 \mathrm{mg} \mathrm{g}^{-1}$. At $5{ }^{\circ} \mathrm{C}$, the highest sucrose level was detected in fruit samples treated with $0.300 \mathrm{mg} \mathrm{g}^{-1}$ of UV-C + hot water on day 8 , while the lowest value was found to be in UV-C application on day 0 with $0.027 \mathrm{mg} \mathrm{g}^{-1}$. According to the results of the analysis, in the 'cv. Sabrina', the highest sucrose value at $0{ }^{\circ} \mathrm{C}$ was found in the control group at $0.466 \mathrm{mg} \mathrm{g}^{-1}$ in the hot water application on $0^{\text {th }}$ day and the lowest value application was in the control group on the $16^{\text {th }}$ day with $0.033 \mathrm{mg} \mathrm{g}^{-1}$. The highest sucrose value at $5{ }^{\circ} \mathrm{C}$ was determined to be $0.466 \mathrm{mg} \mathrm{g}^{-1}$ in hot water application on day 0 , while the lowest value was found to be in the control group with $0.094 \mathrm{mg} \mathrm{g}^{-1}$ on the $8^{\text {th }}$ day (Fig. 6).

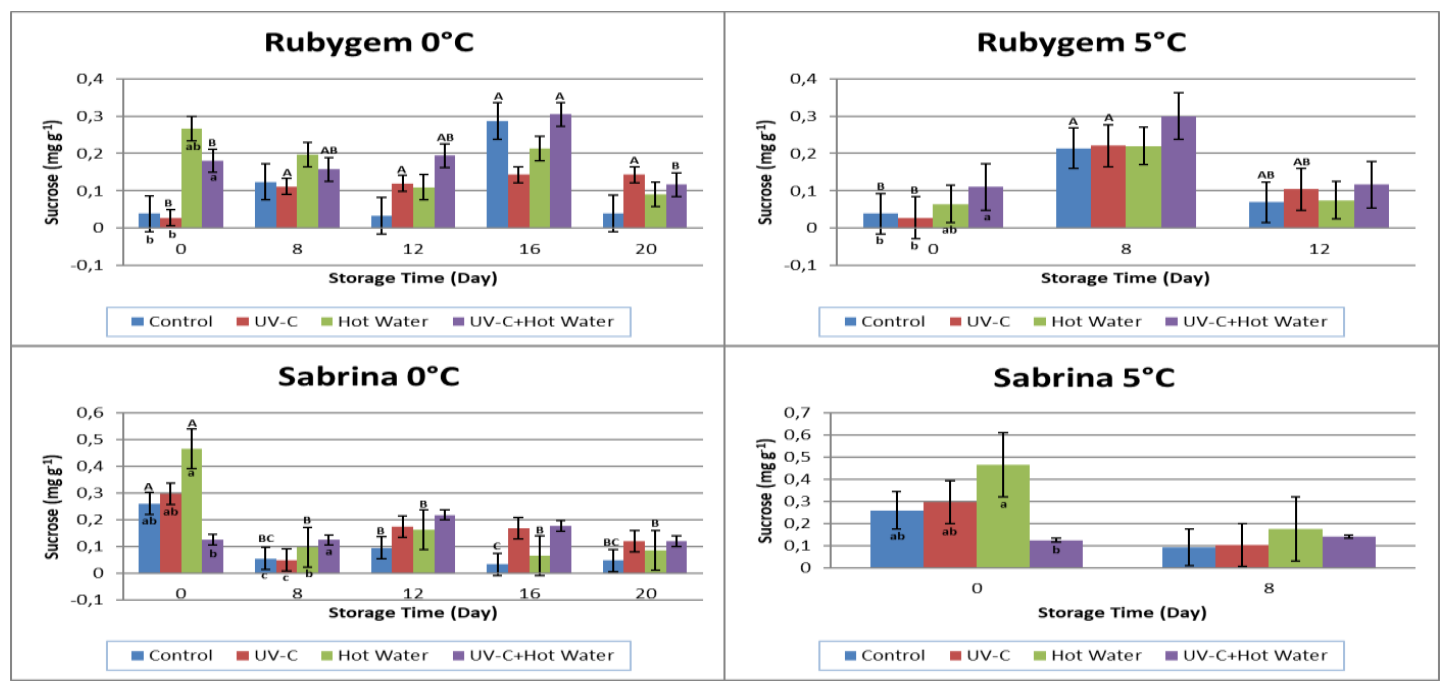

Figure 6. Changes in sucrose value resulting from storage of 'Rubygem' and 'Sabrina' strawberry cultivars at 0 and $5^{\circ} \mathrm{C}$ 
Looking at the changes in maltose value, it was determined that the variations for the 'cv. Rubygem' were parallel to each other, while the 'cv. Sabrina' was found to be fluctuated. In this case, it was determined that the lowest value of the 'cv. Rubygem' was at $0{ }^{\circ} \mathrm{C}$, the highest maltose value was in the control group with $29.497 \mathrm{mg} \mathrm{g}^{-1}$ on day 0 . The lowest value was found in the control group with $4.20 \mathrm{mg} \mathrm{g}^{-1}$ on the $16^{\text {th }}$ day. The highest maltose concentration at $5{ }^{\circ} \mathrm{C}$ was determined in the control group with $29.497 \mathrm{mg} \mathrm{g}^{-1}$ on $0^{\text {th }}$ day, whereas the lowest value application was found to be the control group with $1.178 \mathrm{mg} \mathrm{g}^{-1}$ on $12^{\text {th }}$ day. In the 'cv. Sabrina', the highest maltose value at $0{ }^{\circ} \mathrm{C}$ was found to be $20.094 \mathrm{mg} \mathrm{g}^{-1}$ in UV-C application on day 0 , while the lowest value was found to be $2.592 \mathrm{mg} \mathrm{g}^{-1}$ in UV-C + hot water application on day 8. At $5{ }^{\circ} \mathrm{C}$, the application of the highest maltose value was found to be $20.095 \mathrm{mg} \mathrm{g}^{-1}$ on day 0 with UV-C application, while the lowest value was found to be in the control group with $3.285 \mathrm{mg} \mathrm{g}^{-1}$ on day 8 (Fig. 7).

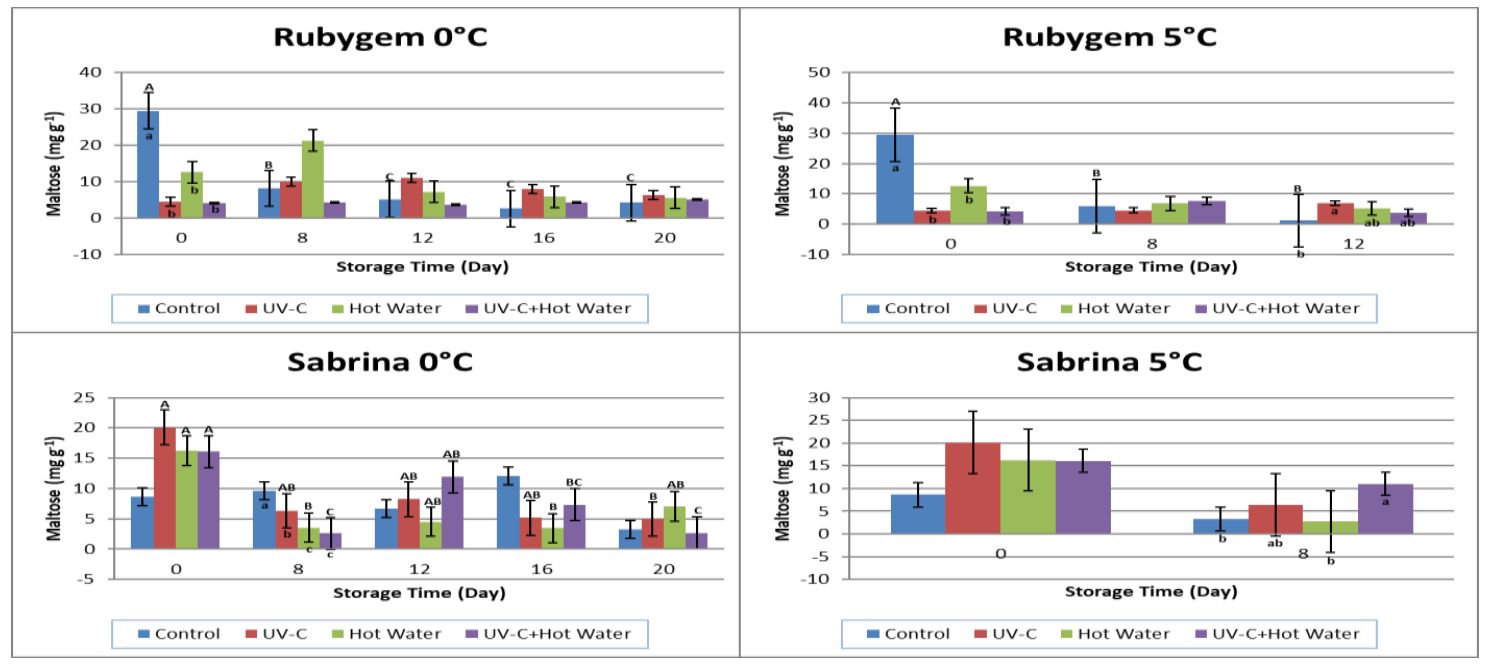

Figure 7. Changes in the maltose value resulting from storage of 'Rubygem' and 'Sabrina' strawberry cultivars at 0 and $5{ }^{\circ} \mathrm{C}$

\section{Discussion}

Statistical analysis among different treatments on total phenolic contents in 'cv. Rubygem' and 'cv. Sabrina' cultivars showed that there was no significant difference in 'cv. Rubygem' stored at $0{ }^{\circ} \mathrm{C}$ in 0,8 and 12 days. On the other hand, the difference between UV-C and hot water applications on the $16^{\text {th }}$ day and also difference between control and UV-C + hot water applications on the $20^{\text {th }}$ day was found statistically significant. The difference between the applications of hot water, UV-C + hot water, and control application on the $8^{\text {th }}$ day was found to be significant, whereas the applications on the $0^{\text {th }}$ and $12^{\text {th }}$ day were not statistically significant when considering the differences between applications at the other storage temperature of $5{ }^{\circ} \mathrm{C}$ (Fig. 1). In the 'cv. Sabrina'; the differences between the applications on days 8, 12 and 20 were not significant. The difference between UV-C + hot water application on day 0 and UV$\mathrm{C}$ application and hot water application on day 16 were significant. Differences between applications at the 'cv. Sabrina' at $5{ }^{\circ} \mathrm{C}$, another storage temperature; UV-C + hot water application was statistically significant at day 0 , whereas it was not significant at day 8 applications (Fig. 1). In both types and temperatures there was a decrease in the total 
amount of phenol in almost all applications. These findings are similar to those of Pan et al. (2004). Results of this study showed that the highest amounts of phenolic substances in 'cv. Rubygem' could be abserved at $0{ }^{\circ} \mathrm{C}$ storage temperature by using hot water and at $5{ }^{\circ} \mathrm{C}$ by using UV-C and hot water treatments. In this study that we have conducted, it has been determined that the application that protects the phenolic materials, which are so important in terms of human health, is hot water application at $0{ }^{\circ} \mathrm{C}$, and UV-C and hot water applications at $5{ }^{\circ} \mathrm{C}$ in the 'cv. Rubygem'. In the 'cv. Sabrina', the result is that the hot water application is the best at both storage temperatures. Previous studies have shown that the total amount of phenolics in strawberries depends on the storage temperature and the composition of the atmosphere (Wang and Zheng, 2001; Ayala-Zavala et al., 2004; Cordenunsi et al., 2005). This high phenolic material in strawberries has increased the shelf life of fruit.

Differences in application with respect to total antioxidant capacity; the difference between the 'cv. Rubygem' and the 'cv. Sabrina' stored at $0{ }^{\circ} \mathrm{C}$ was statistically significant. The difference between the applications in the 'cv. Rubygem' type stored at $5{ }^{\circ} \mathrm{C}$ is significant, while the 'cv. Sabrina' is not significant (Fig. 2). Antioxidant substances naturally occur in plants. These plant antioxidants include anthocyanins and phenolic compounds. It was determined that the amount of antioxidant decreased regularly in both cultivars and 4 different applications. When the applications are evaluated on the basis of the amount of antioxidant in the 'cv. Rubygem', UV-C and hot water application is the application that best protects the amount of antioxidant compound at both storage temperatures. In the 'cv. Sabrina', it is determined that UV-C and hot water applications are the best application for strawberry fruit stored at $0{ }^{\circ} \mathrm{C}$ and control and UV-C + hot water applications for the fruits stored at $5{ }^{\circ} \mathrm{C}$. The successful results have been obtained in terms of protection of antioxidants, especially in applications that we have made in the 'cv. Rubygem'. The study we conducted is similar to that of Vicente et al. (2004) with a study of grape fruits, indicating that the amount of antioxidants decreased both at the end of storage and that hot water and UV$\mathrm{C}$ treatments were effective.

The comparison of different treatments on amounts of vitamin $\mathrm{C}$ showed that in 'cv. Rubygem' at $0{ }^{\circ} \mathrm{C}$, the difference between UV-C + hot water application with UV-C and hot water applications on day 0 was statistically significant. Also, there wer no significant differences among storage days (8, 12, 16 and 20 days). At $5{ }^{\circ} \mathrm{C}$, the difference between applications on day 0 and $12^{\text {th }}$ day of storage were statistically significant, whereas on $8^{\text {th }}$ day was not meaningful (Fig. 3). Difference between applications in the 'cv. Sabrina': at $0{ }^{\circ} \mathrm{C}$, the difference between control and hot water applications of UV-C application was statistically significant at day 0, whereas the difference between applications at 8,12, 16 and 20 days was not significant. At $5{ }^{\circ} \mathrm{C}$, the difference between UV-C and hot water was significant at day 0 and hot water at day 8 and other applications (Fig. 3). Vitamin C values during storage: In the 'cv. Sabrina', except for UV-C applications, there was a decrease in vitamin C value at both temperatures and applications. Both types and at both storage temperatures (except for the 'cv. Sabrina' stored at $5{ }^{\circ} \mathrm{C}$ ) have been the control group that best protects Vitamin C. With this study, both UV-C applications and hot water applications are thought to reduce the amount of vitamin $\mathrm{C}$.

When the changes in sugar content were examined, the difference between the applications of fructose in both types of storage (except the 'cv. Sabrina' at $5{ }^{\circ} \mathrm{C}$ ) was found to be significant (Fig. 4). The difference between the applications at the end of 
the storage of the 'cv. Rubygem' strawberry in terms of glucose was found statistically significant. In the 'cv. Sabrina', the difference between applications was not statistically significant at $0{ }^{\circ} \mathrm{C}$. At $5{ }^{\circ} \mathrm{C}$, the difference between treatments was found to be insignificant on day 0 , whereas on day 8 , control was statistically significant (Fig. 5). When the difference between the applications for sucrose value was examined, the difference between UV-C + hot water application and control and UV-C applications on day 0 in the strawberry cultivars stored at $0{ }^{\circ} \mathrm{C}$ was statistically significant, while the difference between the practices on the day was not statistically significant on days 8 , 12,16 and 20. When the difference between the applications is examined in the 'cv. Rubygem', the difference between UV-C + hot water application and control and UV-C applications was statistically significant on day 0 at $5{ }^{\circ} \mathrm{C}$, whereas the difference between the applications on days 8 and 12 found to be insignificant (Fig. 6). The difference between the application of UV-C and UV-C + hot water at $0{ }^{\circ} \mathrm{C}$ on the $0^{\text {th }}$ day was found to be statistically significant when looking at the difference between applications for the changes in the value of sucrose in the 'cv. Sabrina'. On the $8^{\text {th }}$ day, the difference between control and UV-C applications was not statistically significant, while UV-C + hot water application was statistically significant with hot water, control and UV-C applications. The difference between the applications of storage on the $12^{\text {th }}$, $16^{\text {th }}$ and $20^{\text {th }}$ day was not statistically significant. When the difference between the applications was observed at $5{ }^{\circ} \mathrm{C}$ storage temperature of the 'cv. Sabrina' fruits, the difference between the applications of hot water and UV-C + hot water on the $0^{\text {th }}$ day was significant, but the difference between the applications on the $12^{\text {th }}$ day was not statistically significant (Fig. 6). At $0{ }^{\circ} \mathrm{C}$, maltose content of the 'cv. Rubygem' was statistically significant at day 0 , whereas applications on 8, 12, 16 and 20 days were not statistically significant. At $5{ }^{\circ} \mathrm{C}$, the control application on $0^{\text {th }}$ day and the difference between control and UV-C applications on $12^{\text {th }}$ day was found to be statistically significant in the 'cv. Rubygem' (Fig. 7). The difference between the applications in the 'cv. Sabrina': While the difference between hot water and UV-C + hot water applications at $0{ }^{\circ} \mathrm{C}$ on the $8^{\text {th }}$ day was not statistically significant, the difference between control and UV-C applications of these applications was found statistically significant. The difference between the applications on 0,12,16 and 20 days was not statistically significant. At $5{ }^{\circ} \mathrm{C}$, the difference between control and hot water applications with UV-C + hot water application on the $8^{\text {th }}$ day of the 'cv. Sabrina' was found to be statistically significant (Fig. 7). When fructose, glucose, sucrose and maltose sugar compositions were examined in strawberry fruit, these values decreased in almost all applications at the end of storage. This is why the fruits need energy to perform various reactions inside the cell so that they can survive even when they are picked up. This energy is obtained by using sugars, organic acids and oils present in the fruit. In other words, sugar is used during respiration.

\section{Conclusion}

In this study, the 'cv. Rubygem' and the 'cv. Sabrina' strawberry cultivars were placed in the plastic bags with control, UV-C, hot water and UV-C + hot water applications and stored at 0 and $5{ }^{\circ} \mathrm{C}$, the fruits of the 'cv. Rubygem' were successfully preserved in 4 groups of applications until the $16^{\text {th }}$ day and at the end of $20^{\text {th }}$ day UV-C, hot water and UV-C + hot water applied fruit samples were successfully preserved. Changes in the same fruit samples at $5{ }^{\circ} \mathrm{C}$ were observed for 12 days and during this 
period it was determined that hot water and UV-C + hot water treatments could last 12 days at this storage temperature. When the changes occurred at the end of preservation of the 'cv. Sabrina' are examined, it is thought that fruit samples at $0{ }^{\circ} \mathrm{C}$ can be successfully preserved in all applications up to $12^{\mathrm{th}}$ day. It has been determined that UV-C application in this cultivar is preserved for 16 days, hot water and UV-C + hot water applications are preserved up to 20 days. It was determined that the 'cv. Sabrina' fruit samples kept at $5{ }^{\circ} \mathrm{C}$ lasted for only 8 days. As a result, it was observed that total phenolic contents, total antioxidant activity and sugar were found decrease at the end of storage for both cultivars while fluctuations in vitamin $\mathrm{C}$.

\section{REFERENCES}

[1] Allende, A., Artes, F. (2003): UV-C radiation as a novel technique for keeping quality of fresh processed 'Lollo Rosso' lettuce. - Food Research International 36: 739-746.

[2] Allende, A., McEvoy, J. L., Luo, Y., Artes, F., Wang, C. Y. (2006): Effectiveness of twosided UV-C treatments in inhibiting natural microflora and extending the shelf-life of minimally processed 'Red Oak Leaf' lettuce. - Food Microbiology 23: 241-249.

[3] Araque, L. C. O., Rodoni, L. M., Darré, M., Ortiz, C. M., Civello, P. M., Vicente, A. R. (2018): Cyclic low dose UV-C treatments retain strawberry fruit quality more effectively than conventional pre-storage single high fluence applications. - LWT 92: 304-311.

[4] Aybak, H. Ç. (2005): Çilek Yetiştiriciliği. - Hasat Yayıncılık, İstanbul.

[5] Ayala-Zavala, J. F., Wang, S. Y., Wang, C. Y., Gonzales-Aguilar, G. A. (2004): Effect of storage temperatures on antioxidant capacity and aroma compounds in strawberry fruit. LWT Food Science and Technology 37(7): 687-695.

[6] Barkai-Golan, R., Phillips, D. J. (1991): Postharvest heat treatment of fresh fruits and vegetables for decay control. - Plant Disease 75(11): 1085-1089.

[7] Benzie, I. E. F., Strain, J. J. (1996): Ferric reducing ability of plasma (FRAP) as a measure of "antioxidant power": the FRAP assay. - Analytical Biochemistry 239: 70-76.

[8] Çağlarırmak, N. (2006): Üzümsü Meyvelerde Polifenolik Birleşenlerin İnsan Sağllğ 1 Yönünden Önemleri. - II. Ulusal Üzümsü Meyveler Sempozyumu. 14-16 Eylül 2006, Tokat, pp. 317-321.

[9] Cemeroğlu, B. (2007): Gıda Analizleri. - Gıda Teknolojisi Derneği Yayınları, pp. 168171. No: 34, Ankara, Turkey.

[10] Cordenunsi, B. R., Nascimento, J. R. O., Lajolo, F. M. (2003): Physico-chemical changes related to quality of five strawberry fruit cultivars during cool-storage. - Food Chemistry 83(2): 167-173.

[11] Cordenunsi, B. R., Genovese, M. I., do Nascimento, J. R. O., Hassimotto, N. M. A., Dos Santos, R. J., Lajolo, F. M. (2005): Effects of temperature on the chemical composition and antioxidant activity of three strawberry cultivars. - Food Chemistry 91(1): 113-121.

[12] Couey, H. M. (1989): Heat treatment for control of postharvest diseases and insect pests of fruits. - HortScience 24(2): 198-202.

[13] Darvishi, S., Fatemi, A., Davari, K. (2012): Keeping quality of use of fresh 'Kurdistan' strawberry by UV-C radiation. - World Applied Sciences Journal 17(7): 826-831.

[14] Fallik, E., Aharoni, Y., Yekutieli, O., Wiseblum, A., Regev, R., Beres, H., Bar Lev, E. (1996): A method for simultaneously cleaning and disinfecting agricultural produce. Israel Patent Application No: 116965.

[15] Gao, G., Ren, P., Cao, X., Yan, B., Liao, X., Sun, Z., Wang, Y. (2016): Comparing quality changes of cupped strawberry treated by high hydrostatic pressure and thermal processing during storage. - Food and Bioproducts Processing 100: 221-229.

[16] Karadoğan, B., Keskin, N. (2017): Karaerik (Vitis vinifera L. cv. "Karaerik") klonlarinin kalite ve fitokimyasal özellikleri - Türk Tarım ve Doğa Bilimleri Dergisi 4(2): 205-212. 
[17] Keskin, N., Kunter, B. (2017): Stilbenes profile in various tissues of grapevine (Vitis vinifera L. cv. 'Ercis'). - Journal of Environmental Protection and Ecology 18(3): 12591267.

[18] Keskin, N., Baytin, M. S., Çavuşoğlu, Ş., Türkoğlu, N., Baytin, R., Parlar, Ç. (2014): Erciş üzüm çeşidinde hasat sonrası UV-C ve sıcak su uygulamalarının meyve kalitesi ve soğukta muhafaza üzerine etkileri. - 6. Bahçe Ürünlerinde Muhafaza ve Pazarlama Sempozyumu Bildiri Kitab1, pp. 39-44.

[19] Keskin, N., Keskin, S., Çavuşoğlu, Ş, Şevgin, N., Kunter, B., Karadoğan, B., Kalkan, N. N. (2015): Karaerik (Cimin) üzüm çeşidinde hasat sonrası UV-C ve sıcak su uygulamalarının meyve kalitesi ve soğukta muhafaza üzerine etkileri. - GAP VII. Tarım Kongresi Bildiri Kitab1, pp. 34-40.

[20] Lurie, S. (1998): Postharvest heat treatments. - Postharvest Biology and Technology 14: 257-269.

[21] Marquenie, D., Michiels, C. W., Van Impe, J. F., Schrevens, E., Nicolai, B. N. (2003): Pulsed white light in combination with UV-C and heat to reduce storage rot of strawberry. - Postharvest Biology and Technology 28: 455-461.

[22] Özgökçe, G. (2016): Van Ekolojik Koşullarında Yetiştirilen Bazı Standart ve Yerel Yeşil Fasulye (Phaseolus vulgaris L.) Çeşitlerinde Hasat Sonrasında Meydana Gelen Değişimlerin Belirlenmesi (Yüksek Lisans Tezi, basılmamış). - Yüzüncü Yıl Üniversitesi, Fen Bilimleri Enstitüsü, Van.

[23] Pan, J., Vicente, A. R., Martínez, G. A., Chaves, A. R., Civello, P. M. (2004): Combined use of UV-C irradiation and heat treatment to improve postharvest life of strawberry fruit. - Journal of the Science of Food and Agriculture 84(14): 1831-1838.

[24] Romanzzi, G., Nigro, F., Ippolito, A., Salerno, M. (2001): Effect of short hypobaric treatments on postharvest rots of sweet cherries, strawberries and table grapes. Postharvest Biology and Technology 22(1): 1-6.

[25] Silva, F. M., Chau, K. V., Brecht, J. K., Sargent, S. A. (1999): Modified atmosphere packaging for mixed loads of horticultural commodities exposed to two postharvest temperatures. - Postharvest Biology and Technology 17(1): 1-9.

[26] Swain, T., Hillis, W. E. (1959): The phenolic constituents of Prunus domestica I. - The quantitative analysis of phenolic constituents. - Journal of the Science of Food and Agriculture 10: 63-68.

[27] Vicente, A., Repice, B., Martinez, G., Chaves, A., Civello, P., Soz, G. (2004): Maintenance of fresh boysenberry fruit quality with UV-C light and heat treatments combined with low storage temperature - The Journal of Horticultural Science and Biotechnology 79(2): 246-251.

[28] Vinson, J. A., Su, X., Zubik, L., Bose, P. (2001): Phenol antioxidant quantity and quality in foods: fruits. - Journal Agriculture and Food Chemistry 49: 5315-5321.

[29] Wang, H., Cao, G., Proir, R. L. (1996): Total antioxidant capacity of fruits. - Journal of Agriculture and Food Chemistry 44: 701-705.

[30] Wang, S. Y., Zheng, W. (2001): Effect of plant growth temperature on antioxidant capacity in strawberry. - Journal of Agriculture and Food Chemistry 49: 4977-4982. 